Siedlecki Zygmunt, Hadzik Kajetan, Woźniak Jakub, Śniegocki Maciej. Vacuum - assisted closure in neurosurgery as treatment option for purulent wounds after spinal implants procedures - short preliminary report. Journal of Education, Health and Sport. 2022;12(2):89-93. eISSN 2391-8306. DOI http://dx.doi.org/10.12775/JEHS.2022.12.02.010

https://apcz.umk.pl/JEHS/article/view/JEHS.2022.12.02.010

https://zenodo.org/record/5992623

The journal has had 40 points in Ministry of Education and Science of Poland parametric evaluation. Annex to the announcement of the Minister of Education and Science of December 21, 2021. No. 32343. Has a Journal's Unique Identifier: 201159. Scientific disciplines assigned: Physical Culture Sciences (Field of Medical sciences and health sciences); Health Sciences (Field of Medical Sciences and Health Sciences).

Punkty Ministerialne z 2019 - aktualny rok 40 punktów. Zalącznik do komunikatu Ministra Edukacji i Nauki z dnia 21 grudnia 2021 r. Lp. 32343. Posiada Unikatowy Identyfikator Czasopisma: 201159. Przypisane dyscypliny naukowe:Nauki o kulturze fizycznej (Dziedzina nauk medycznych i nauk o zdrowiu); Nauki o zdrowiu (Dziedzina nauk medycznych i nauk o zdrowiu).

(c) The Authors 2022;

This article is published with open access at Licensee Open Journal Systems of Nicolaus Copernicus University in Torun, Poland

Open Access. This article is distributed under the terms of the Creative Commons Attribution Noncommercial License which permits any noncommercial use, distribution, and reproduction in any medium,

provided the original author (s) and source are credited. This is an open access article licensed under the terms of the Creative Commons Attribution Non commercial license Share alike.
(http://creativecommons.org/licenses/by-nc-sa/4.0/) which permits unrestricted, non commercial use, distribution and reproduction in any medium, provided the work is properly cited.

The authors declare that there is no conflict of interests regarding the publication of this paper.

Received: 26.01.2022. Revised: 26.01.2022. Accepted: 07.02.2022.

\title{
Vacuum - assisted closure in neurosurgery as treatment option for purulent wounds after spinal implants procedures - short preliminary report
}

\author{
Zygmunt Siedlecki, Kajetan Hadzik, Jakub Woźniak, Maciej Śniegocki
}

Department of Neurosurgery, Neurotraumatology and Pediatric Neurosurgery, The Ludwik Rydygier Collegium Medicum in Bydgoszcz, The Nicolaus Copernicus University in Toruń

Corresponding address:

Dr. med. Zygmunt Siedlecki Department of Neurosurgery, Neurotraumatology and Pediatric Neurosurgery,

the Ludwik Rydygier Collegium Medicum in Bydgoszcz,

tel.: + 48606302680

e-mail: siedlecki@cm.umk.pl

\begin{abstract}
We present a short preliminary report about the use of vacuum - assisted closure in infected and purulent wounds treatment after neurosurgical spinal procedures. Our report is based on the currently treated patients and points out to other neurosurgeons this therapeutic possibility. We are currently treating two severely injured patients in bad functional state. These patients had severe spine injuries and were therefore treated surgically by decompression and fusion. Patient No. 1 had C5 burst fracture treated by anterior and posterior stabilization, while patient No. 2 had Th4 burst fracture treated with posterior transpedicular stabilization. The patients developed purulent surgical site infection. Revision and wounds irrigation were ineffective. Desire to leave titanium implants in patient's spines (which is important for future rehabilitation), it was decided to use V.A.C ${ }^{\circledR}$ in wounds healing.
\end{abstract}


We find that vacuum - assisted closure appears to be of significant benefit in such treatment. It is a good therapeutic option in the management of such patients; however, this issue requires more extensive research in the future.

Key words: vacuum - assisted closure, neurosurgery, spine, wound

\section{Introduction}

Vacuum - assisted closure (V.A.C®, VAC) is a system widely used in surgery for the treatment of difficult-to-heal wounds. It was introduced in 1991 and since then VAC. it is used in patients worldwide and is thought as one of the major life-saving advances in the treatment of difficult wounds [1,2]]. It is used in the treatment of acute traumatic wounds and severe burns, wounds with separated edges technically impossible for simple surgical suturing [2]. VAC is also used in mesh grafting, in ulcers treatment, diabetic foot, and venous insufficiency ulcers. The V.A.C ${ }^{\circledR}$ consists of foam dressings (which may optionally contain silver compounds) and suction. V.A.C $®$ is used in the treatment and care of wounds, both in intensive care (in surgical and intensive care hospitals) and at home [2,3]. When used on open wounds, their are aimed at creating an environment conducive to wound healing by granulation and scar development. The mechanism is preparing the wound tissue for closure, reducing edema, VAC supports the formation of granulation and perfusion, as well as removing exudate and infectious material - purulent [3]. Silver complex foam dressing may be used for wounds with surgical site infection (SSI). It is an effective barrier to the penetration of bacteria and may help reduce infection [4]. When applied to closed surgical wounds, is aimed at creating an environment that allows drainage to continue after suturing with sutures or staples by keeping the wound closed and removing exudate through the use of vacuum wound therapy. VAC must not be applied directly to exposed blood vessels, anastomotic sites, organs or nerves [5]. VAC is not indicated in patients with neoplastic processes in the wound, with untreated osteomyelitis, with intestinal and unexplored fistulas, and with necrotic tissue with a scab $[5,6]$.

\section{Case descriptions}

In 2021, we first time used VAC in patients after spinal surgery with wound healing complications and purulent SSI.

Patient No. 1 was 35 years old male after severe cervical spine C5, C6 fracture, who had previously been operated on both anterior and posterior approach. The patient had implants: vertebral body prosthesis, an anterior titanium plate, and posteriorly laminar hooks and two rods. The patient developed SSI with purulent leak through the skin. Antibiotics were used and a two-stage procedure of revision of the operating bed was performed, including irrigation, drainage, and suturing. However, we decided not to remove the implants. When the wound was not healed, VAC was applied. VAC was maintained for 3 weeks with periodic replacement of the sponges every 4 days. After this time, VAC was removed, and the wound was sutured. The patient was in a severely functional state, cachectic, paralyzed tetraplegia, 
and respiratory insufficiency secondary to spinal cord injury. The patient died secondary to severe systemic complications; however, VAC was a favorable option in the healing of severe purulent SSI.

Patient No. 2 was a 75-year-old woman with a Th5 fracture and after surgery: percutaneous pedicle screw fixation and laminectomy. After surgery, there was a purulent leak from the upper wound above two titanium screws. In this case, the wound was treated twice, then a VAC was applied, after removing the VAC, the wound continued to heal for a long time and unfavorably, eventually granulation occurred. In the authors' opinion, the use of VAC accelerated the formation of granulation tissue and was beneficial. The patient also remained in a poor functional condition (Glasow Outcome Scale 5) and was discharged to a social and nursing center.

\section{Results}

These two cases are only a preliminary report on the use of VAC in complicated and infected wounds after spine surgery. Authors had never used VAC before (before 2021), but in the authors' opinion it is a valuable therapeutic option.

\section{Literature review}

However, according to, V.A.C® producer it cannot be applied directly to the nerves, from a neurosurgical point of view, this recommendation is too general to clarify the use of VAC In neurosurgical practice, a complicated wound may contain the thecal sac, nerve roots, meningeal structures, brain, subarachnoid space or peripheral nerves. There are reports in the literature on both VAC in neurosurgical cases of the head / brain / skull procedure and spine / vertebral canal procedure. Due to our initial experience with VAC in spine surgery, we reviewed the literature on this topic.

Labler et al. (2006) described the use of VAC in postoperative infections after dorsal spinal surgery [7]. He defined successful treatment as a stable healed wound that showed no signs of acute or chronic infection. In his study the treatment of the infected back wounds consisted of repeated debridement, irrigation and open wound treatment with temporary closure by VAC Implants was exchanged or removed if necessary [7] in contrast to our observations (in our two cases implants they were left in the spine. Lablar emphasized that antibiotics were necessary in all cases. In his study follow had been possible in 14 patients [7]. One patient showed a new infection after treatment. Labner showed the usefulness of VAC therapy as a new alternative management for wound conditioning after deep subfascial infection in spine surgery cases [7].

Jones et al. (2007) noted that deep infections of the spine are a significant cause of morbidity and death and such infections complicate 0.7 to $11.9 \%$ of spinal procedures [8]. He noted that VAC was alternative for treatment of patients with complex postoperative spinal infections and he investigated the safety of this treatment method in this patient population on the basis of16 consecutive patients treated with negative -pressure wound therapy [8]. Jones concluded that VAC had been employed as a treatment strategy for patients with complex postoperative spinal infections [8]. However he emphasized that little was known of the complications associated with VAC in the spinal surgery patient population and potential serious complications, including death, might be associated with the VAC using [8].

Canavese et al. (2008) described 14 patients with early deep spinal infection treated using VAC In his study, similar to our description no patient was implants removed and there was no loss of correction or recurrent infection [9]. He emphasized that we believed that VAC was a useful tool for spinal surgeon dealing with wound infections, especially those with 
neuromuscular Diseases [9]. According to Canavese VAC allowed for the implants retention and was reliable and easy to use [9].

Kale et al. (2017) also noted that post - operative wound infections after spinal surgery were a very serious problem, leading to a risk of significant morbidity [10], what coincides with Jones et al. (2007) observations [8]. Kale described treatment 12 patients using VAC and in his study one of the patients needed a partial implant exchange although none of the cases needed complete implant removal [10]. He demonstrated the usefulness of VAC therapy as an alternative management for wound conditioning of a back wound with the high complexity in nature after instrumented spine surgeries as it eliminates complex secondary surgeries, prolong use of antibiotics and removal of the implants [10].

Lee et al. (2018) noted that using VAC over exposed dura was controversial and the outcome has not been reported in large series [11]. He presented one of the largest studies which confirmed the safety and efficacy of VAC in patients with spinal wound infections, even when the dura was exposed [11]. In our cases dura was exposed in every patient.

Dyck et al. (2019) described 21 patients with SSI after spine surgery treated using VAC versus 43 patients who received standard wound dressings [12]. He observed that VACtreated patients were malnourished $(\mathrm{p}=0.020)$. V.A.C.- treated patients underwent longer surgeries $(p<0.001)$ and required more postoperative ICU admissions $(p=0.039)$ [12]. The median length of hospital stay was not different between groups. In total, 9 control patients (21\%) developed an SSI, versus 2 VAC-treated patients (10\%) [12]. Dyck concluded that however, VAC application to the postoperative incision resulted in a $50 \%$ reduction in SSI. No adverse effects were noted secondary to VAC application [12].

\section{Conclusions}

Vacuum - assisted closure is an option for treating complicated and infected wounds after spine surgery with implants. VAC using after spine surgery has been described in the literature since 2006, therefore this method seems to be an acceptable option in spine surgery. Despite the controversy, it seems that vacuum-assisted closure can be used on the exposed dura and that previously used implants can be left in the spine.

\section{Abbreviations}

- SSI - surgical site infection

- VAC, V.A.C® - vacuum - assisted closure

Conflicts of interest - The authors declare that they have no conflict of interest.

\section{References:}

1. IuA, D., Larichev, A. B., \& AIu, A. (1992). Wound healing after vacuum drainage. Khirurgiia, (7-8), 21-26.

2. Argenta, L. C., \& Morykwas, M. J. (1997). Vacuum-assisted closure: a new method for wound control and treatment: clinical experience. Annals of plastic surgery, 38, 563-577.

3. Venturi, M. L., Attinger, C. E., Mesbahi, A. N., Hess, C. L., \& Graw, K. S. (2005). Mechanisms and clinical applications of the vacuum-assisted closure (VAC) device. American journal of clinical dermatology, 6(3), 185-194.

4. Morykwas, M. J., Simpson, J., Punger, K., Argenta, A., Kremers, L., \& Argenta, J. (2006). Vacuum-assisted closure: state of basic research and physiologic foundation. Plastic and reconstructive surgery, $117(7 \mathrm{~S}), 121 \mathrm{~S}-126 \mathrm{~S}$.

5. Argenta, L. C., Morykwas, M. J., Marks, M. W., DeFranzo, A. J., Molnar, J. A., \& David, L. R. (2006). Vacuum-assisted closure: state of clinic art. Plastic and reconstructive surgery, 117(7S), 127S-142S. 
6. Scherer, S. S., Pietramaggiori, G., Mathews, J. C., Prsa, M. J., Huang, S., \& Orgill, D. P. (2008). The mechanism of action of the vacuum-assisted closure device. Plastic and reconstructive surgery, 122(3), 786-797.

7. Labler, L., Keel, M., Trentz, O., \& Heinzelmann, M. (2006). Wound conditioning by vacuum assisted closure (VAC) in postoperative infections after dorsal spine surgery. European Spine Journal, 15(9), 1388-1396.

8. Jones, G. A., Butler, J., Lieberman, I., \& Schlenk, R. (2007). Negative-pressure wound therapy in the treatment of complex postoperative spinal wound infections: complications and lessons learned using vacuum-assisted closure. Journal of Neurosurgery: Spine, 6(5), 407-411.

9. F Canavese, S Gupta, JI Krajbich, KM Emara. The Journal of bone and joint surgery. British volume - 2008 - online.boneandjoint.org.uk

10. Kale, M., Padalkar, P., \& Mehta, V. (2017). Vacuum-assisted closure in patients with post-operative infections after instrumented spine surgery: a series of 12 cases. Journal of Orthopaedic Case Reports, 7(1), 95.

11. Lee, R., Beder, D., Street, J., Boyd, M., Fisher, C., Dvorak, M., ... \& Kwon, B. (2018). The use of vacuum-assisted closure in spinal wound infections with or without exposed dura. European Spine Journal, 27(10), 2536-2542.

12. Dyck, B. A., Bailey, C. S., Steyn, C., Petrakis, J., Urquhart, J. C., Raj, R., \& Rasoulinejad, P. (2019). Use of incisional vacuum-assisted closure in the prevention of postoperative infection in high-risk patients who underwent spine surgery: a proof-of-concept study. Journal of Neurosurgery: Spine, 31(3), 430-439. 